\title{
PECULIARITIES OF CHARGE CARRIER RELAXATION IN GRAIN BOUNDARY OF GADOLINIUM-DOPED CERIA CERAMICS
}

\author{
S. Kazlauskas ${ }^{\text {a }}$, E. Kazakevičius ${ }^{a}$, A. Žalga ${ }^{\text {b }}$, S. Daugèla ${ }^{\text {a }}$, and A. Kežionis ${ }^{\text {a }}$ \\ ${ }^{a}$ Institute of Applied Electrodynamics and Telecommunications, Sauletekio 3, 10222 Vilnius, Lithuania \\ ${ }^{\mathrm{b}}$ Department of Applied Chemistry, Faculty of Chemistry and Geosciences, Vilnius University, Naugarduko 24, \\ 03225 Vilnius, Lithuania \\ Email: saulius.kazlauskas@ff.vu.lt
}

Received 25 February 2019; revised 28 March 2019; accepted 2 April 2019

\begin{abstract}
Two different gadolinium-doped ceria ceramics are prepared from two different powders, one commercially available synthesised by solid state reaction and another produced by tartaric acid assisted sol-gel synthesis. The specimens have a different microstructure, while the XRD patterns of powders showed a pure cubic fluorite structure without any impurity phase. The electrical properties are studied at frequencies up to $10 \mathrm{GHz}$ by combining broadband 2-electrode and 4-electrode impedance spectroscopy methods. Primary electrical measurements showed that the values of grain conductivity and its activation energies for both ceramics were nearly the same. However, due to different contributions of the grain boundary mediums, total conductivities and their activation energies are found to be considerably different. The advantage of the 4-electrode method allowed us to measure the pure electrical response of grain boundaries, bypassing any interferences caused by interfacial impedance. By using these data, the temperature behaviour of distribution of relaxation times in the grain boundary is studied. A broadening of this distribution with increasing temperature is found for both specimens, contrary to a previously observed phenomenon in the grain of oxygen ion conductive ceramics and single crystals. It is shown that, supposing individual relaxation times behave according to the Arrhenius law, both activation energy and pre-exponential factor must be distributed.
\end{abstract}

Keywords: gadolinium-doped ceria, ionic conductivity, distribution of relaxation times, grain boundary, sintering

PACS: 81.05.Je, 66.30.Dn

\section{Introduction}

Gadolinia-doped ceria (GDC) is a promising solid electrolyte material for solid oxide fuel cells and other solid oxide devices. Many efforts have been made for improvement of its ionic conductivity. The effects of dopant concentration [1-4], grain size [5, 6], synthesis [7, 8] and processing [9], 10] on electrical properties have been comprehensively studied. However, the vast majority of recent works dealing with electrical properties of GDC ceramics still encountered a pretty low total conductivity due to a high resistivity of grain boundaries [9, 11-22].
The electrical properties of grain boundary of GDC ceramics are comprehensively studied in a number of works. For example, Arabaci et al. [19] revealed a decreasing trend in the resistivity of grain boundary for 10GDC with increasing sintering temperature. Reddy et al. [9] determined different activation energies of grain boundary conductivity for 10GDC ceramics sintered at 1373 and $1673 \mathrm{~K}$. The effect of sintering temperature on the electrical properties of GDC ceramics was also studied in our previous work [23].

However, in most previous studies [9-19], grain boundary measurements were carried out by the 2-electrode method. This restricted the 
opportunities to measure the pure electrical response of grain boundary due to the sample-electrode interface polarization effect. Besides, these studies have employed the impedance measurement equipment with a high-frequency limit of $10 \mathrm{MHz}$, which was found to be too low to obtain electrical responses of GDC grain and grain boundary at temperatures higher than $673 \mathrm{~K}$ [9 15, 18, 19] and $823 \mathrm{~K}[15,18,19]$, respectively.

The only few exceptions are works [20, 23] dealing with experimental data obtained by the 4-electrode method, which eliminates an unwanted sample-electrode interface response. However, even the latter studies were not dealing with a more detailed analysis of the character of electrical response of grain boundaries.

By this study we aimed to investigate and compare the electrical properties of $\mathrm{Ce}_{0.9} \mathrm{Gd}_{0.1} \mathrm{O}_{1.95}$ ceramics prepared from differently synthesised powders. Electrical measurements were carried out at frequencies up to $10 \mathrm{GHz}$ by even more advanced techniques than in our previous study [23]. Grain and grain boundary contributions to total conductivity were measured by combining 2- and 4-electrode methods at temperatures up to $1000 \mathrm{~K}$. The advantage of high quality experimental data allowed us to study not only the electrical properties of the ceramics, but also to detect common regularities of charge carrier relaxation in the grain boundaries of differently sintered GDC ceramics.

\section{Experiment}

The commercial powder (10GDC $_{\text {com }}$ produced by Fuel Cell Materials) with a surface area of $S_{\text {BET }}=6.44 \mathrm{~m}^{2} / \mathrm{g}$ has been synthesised by the solid state reaction. The second powder $\left(10 \mathrm{GDC}_{\mathrm{sg}}\right)$ was prepared by the tartaric acid assisted (TAS) sol-gel synthesis. The latter synthesis was as follows: gadolinium (III) oxide $\left(\mathrm{Gd}_{2} \mathrm{O}_{3}, 99.9 \%\right.$ AlfaAesar $)$ and ammonium cerium $(\mathrm{VI})$ nitrate $\left(\left(\mathrm{NH}_{4}\right)_{2} \mathrm{Ce}\left(\mathrm{NO}_{3}\right)_{4}\right.$, 99.99\% Sigma-Aldrich) were used as starting materials in the synthesis of $10 \mathrm{GDC}_{\mathrm{sg}}$ powder. Nitric acid $\left(\mathrm{HNO}_{3}, 66 \%\right.$ Reachem $)$ and distilled water were used as reagents to reduce the $\mathrm{pH}$ of the solutions and to improve the solubility of gadolinium oxide. Tartaric acid ( $\mathrm{L}-(+)-$ Tartaric acid $\left(\mathrm{C}_{4} \mathrm{H}_{6} \mathrm{O}_{6}\right)$ (TA), $\geq 99.5 \%$ Sigma-Aldrich) was applied for the escalation of solubility via coordination of starting compounds in the reaction mixture, especially during the $\mathrm{pH}$ changes and evaporation before sol-gel formation. At first, ammonium cerium (VI) nitrate was dissolved in distilled water at $353 \mathrm{~K}$. After several minutes of mixing and evaporating in an open beaker, the reduction of $\mathrm{Ce}^{4+}$ ions to $\mathrm{Ce}^{3+}$ was completed by adding tartaric acid. This oxidation-reduction process of ammonium cerium (VI) nitrate in water and tartaric acid solution was confirmed by both the observation of the release of a large amount of $\mathrm{CO}_{2}$ gases and the change of the colour of the solution from orange to colourless. Next to that, gadolinium (III) oxide and concentrated nitric acid were added to the beaker. A clear solution was obtained and subsequently concentrated by fast vapourising of the reaction mixture at $368 \mathrm{~K}$. In the following stage, a yellow transparent sol was formed after nearly $95 \%$ of the water has been evaporated under continuous stirring. After drying at $393 \mathrm{~K}$ for several hours, fine-grained pale yellow gel powder was obtained. This $\mathrm{Gd}-\mathrm{Ce}-\mathrm{O}$ tartrate gel precursor for GDC ceramics was heat-treated at $1273 \mathrm{~K}$ for 5 hours.

The crystal structure of powders was determined by X-ray diffraction (XRD) analysis on a PANalytical X'Pert MPD PRO diffractometer $(\mathrm{CuK} \alpha$ radiation wavelength $=1.54051 \AA)$. The Rietveld refinement of the obtained XRD patterns was performed using the X'Pert HighScore Plus software. The samples were made by uniaxial cold pressing of the powders in a steel die. The compacts were sintered at $1573 \mathrm{~K}$ temperature in air atmosphere for 2 hours $\left(10 \mathrm{GDC}_{\mathrm{com}}\right)$ and at $1623 \mathrm{~K}$ for 5 hours $\left(10 \mathrm{GDC}_{\mathrm{sg}}\right)$. Surfaces of the obtained specimens were observed by scanning electron microscopy.

Measurements of the electrical properties at frequencies from $10 \mathrm{~Hz}$ to $2 \mathrm{MHz}$ were carried out by an upgraded equipment of the 4-electrode method [24]. Corresponding investigations in the frequency range from $10 \mathrm{~Hz}$ to $10 \mathrm{GHz}$ were carried out by an ultrabroadband impedance spectrometer [25]. For the 4-electrode method rectangular samples $(8 \times 1.5 \times 1.5 \mathrm{~mm})$ were used, whereas for the 2-electrode technique cylindrical samples $1.5 \mathrm{~mm}$ high and $2.5 \mathrm{~mm}$ in diameter were prepared. The electrodes of the samples were prepared using Pt paste made by Gwent Electronic Materials LTD, fired at $1200 \mathrm{~K}$. 


\section{Results and discussion}

The results of the XRD study have shown that the powders have a cubic fluorite structure without additional impurity phases (Fig. 2, ICSD No.: 28795). The values of the corresponding lattice parameter, grain size and relative density of the ceramics are presented in Table 1. Scanning electron microscopy has shown that most of $10 \mathrm{GDC}_{\text {com }}$ grains are in a range of $0.5-1.5 \mu \mathrm{m}$ (Fig. 1). The $10 \mathrm{GDC}_{\mathrm{sg}}$ samples were found to have larger grains with an average size of $1.5 \mu \mathrm{m}$. By using different technologies of powder synthesis and different sintering conditions of ceramics, these were prepared with the same phase and stoichiometric composition, but different microstructural parameters.

The electrical properties of ceramics were examined at temperatures from 400 to $1000 \mathrm{~K}$. Typically the dispersion regions are observed in the impedance $\left(\widetilde{z}=z^{\prime}-\mathrm{i} z\right.$ ') and permittivity spectra of oxide ionic conductors [26, 27]. In most cases the use of data measured by the 4-electrode method allowed us to obtain dc resistivity values by simple extrapolation to the real axis of semicircles in the complex impedance plots. In the cases when the data measured by the 2-electrode method was employed, or impedance semicircles from 4-electrode data were strongly overlapped, the fitting of impedance spectra to the response of the socalled ZARC elements [28] was used. To model the impact of the high-frequency dielectric constant $\varepsilon_{\infty}$ the capacitance was added to the ZARC of grains.

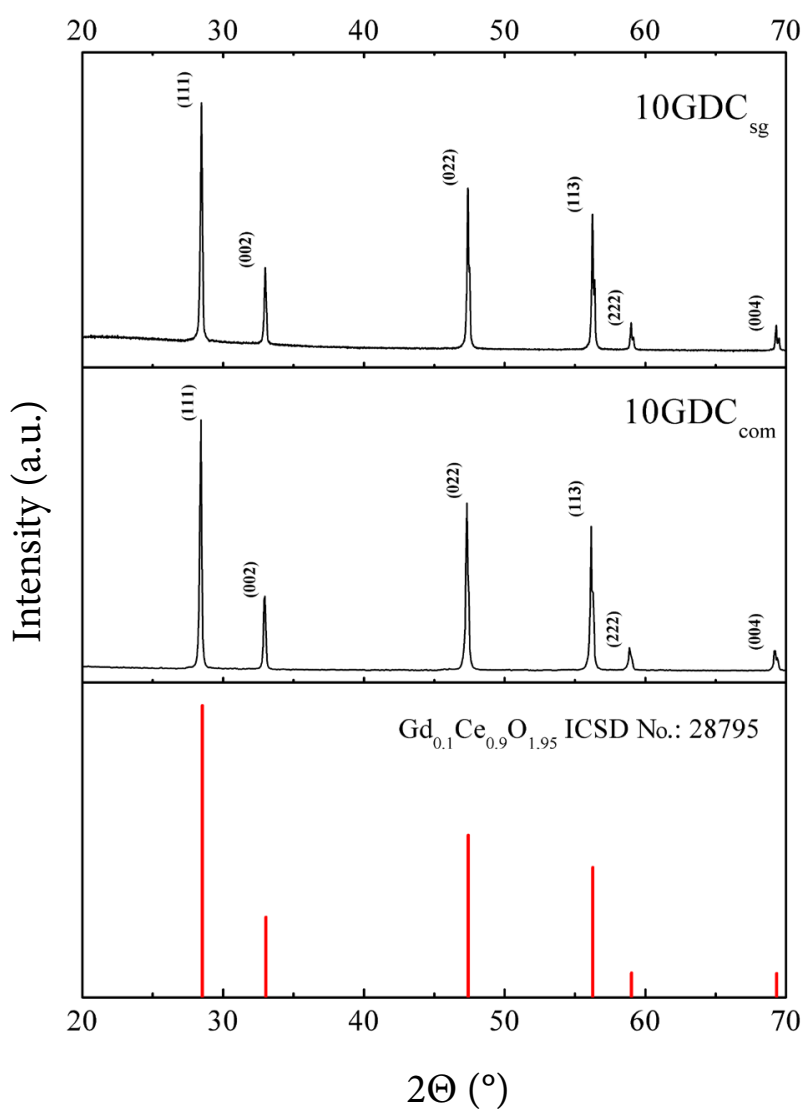

Fig. 2. XRD patterns of powders at room temperature.

Primary results of the conductivity analysis revealed that grain conductivity values were nearly the same for both investigated ceramics (Fig. 3). The observed slight differences are caused most likely by deviations from the stoichiometric composition in powders received from different sources.

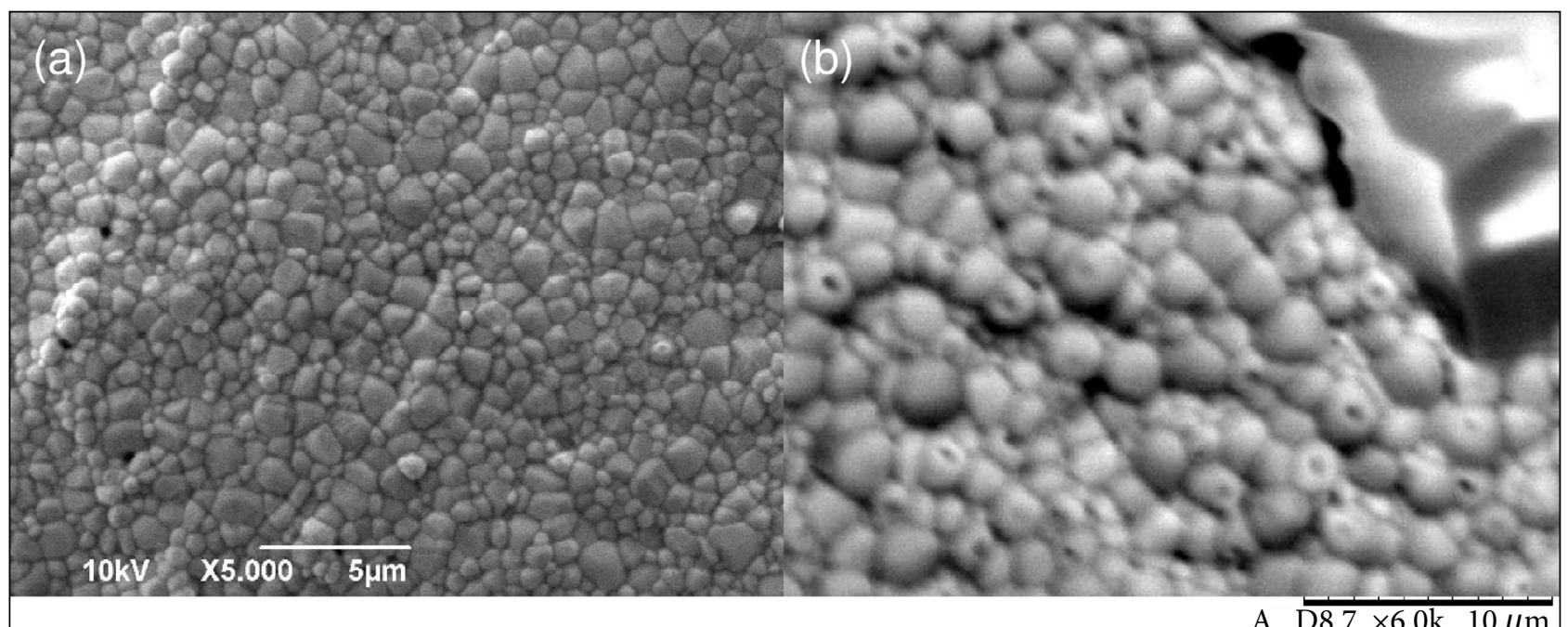

A $\overline{\mathrm{D} 8.7 \times 6.0 \mathrm{k} 10 \mu \mathrm{m}}$

Fig. 1. SEM images of (a) $10 \mathrm{GDC}_{\mathrm{com}}$ and (b) $10 \mathrm{GDC}_{\mathrm{sg}}$ ceramics. 


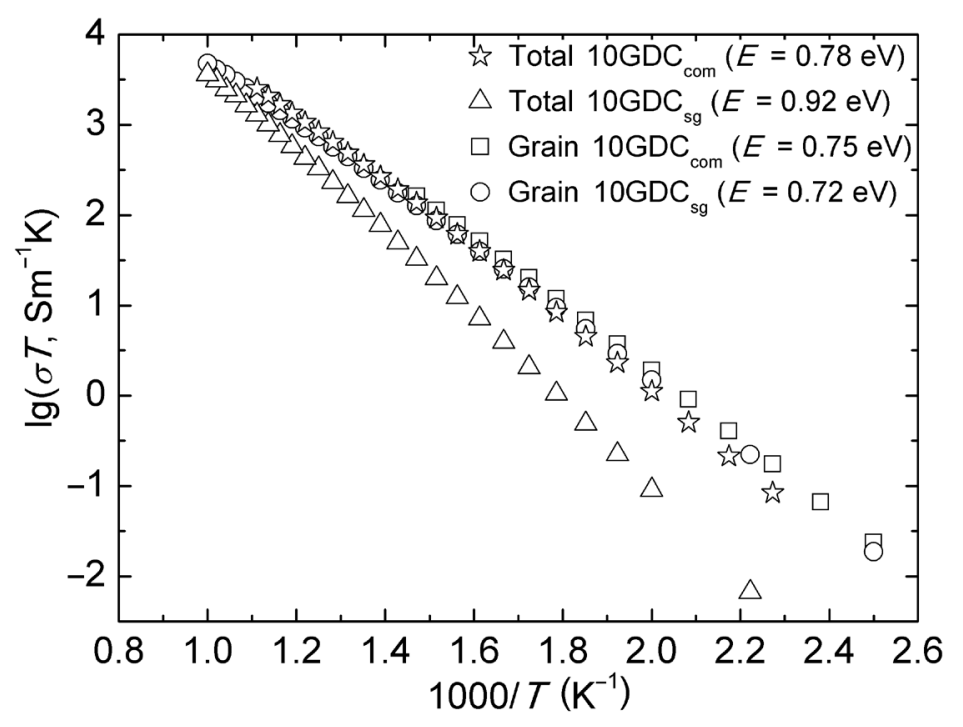

Fig. 3. Temperature dependences of total and grain conductivity values.
The obtained grain conductivity values and activation energies for $10 \mathrm{GDC}_{\mathrm{com}}$ and $10 \mathrm{GDC}_{\mathrm{sg}}$ were found to be in close agreement with the previously reported data for bulk 10GDC ceramics [9], 16]. However, total conductivities were considerably different for $10 \mathrm{GDC}_{\text {com }}$ and for $10 \mathrm{GDC}_{\mathrm{sg}}$ (Fig. 3), and showed different activation energies, indicating different contributions of the grain boundaries. The values of grain, total, grain boundary conductivities (at $673 \mathrm{~K}$ ) and corresponding activation energies are presented in Table 1. The values of total conductivity and the activation energy of total conductivity are heavily related to the preparation and microstructure of ceramics and are quite widely scattered in scientific literature. For example, the activation energy covers the range from 0.66 to $0.93 \mathrm{eV}[9,11-13,15,16,19$.

Examples of the complex impedance plane plots are presented in Figs. $4(a, b)$, where nearly complete left-hand side semicircles are attributed to the grains of ceramics, and low-frequency semicircles are related to grain boundaries. It may be noticed that the impedance data (Fig. 4(b)) obtained by 2-electrode and 4-electrode methods do not match in the low-frequency region due to the interfered grain boundary and interface responses in the case of 2-electrode data. By taking advantage of the 4-electrode method, the sample-electrode interface was eliminated and therefore it did not appear in the plot. It is also evident that due to the high conductivity of $10 \mathrm{GDC}_{\mathrm{sg}}$, the grain response moves to frequencies higher than $100 \mathrm{MHz}$ at $980 \mathrm{~K}$.

Contributions of the grain boundary medium, presented in Fig. 5, confirm the expected difference in the resistivity values of $10 \mathrm{GDC}_{\mathrm{com}}$ and $10 \mathrm{GDC}_{\mathrm{sg}}$ grain boundaries. The grain boundary resistivities $z_{\mathrm{gb}}$, shown in Fig. 5, are normalised to the geometric factor of the samples, since the actual specific resistivity or conductivity of the grain boundary medium remains unknown due to uncertainty of the volume occupied by the grain boundary. The obtained activation energies for the resistivity of the grain boundary are in agreement with the values found in the literature $(0.94$ and $1.2 \mathrm{eV}$ for $10 \mathrm{GDC}$ ceramics sintered at 1373

Table 1. Summary of the values of parameters collected from XRD, SEM (at room temperature) and impedance measurements (at $673 \mathrm{~K}$ ).

\begin{tabular}{c|c|c|c|c|c|c|c|c|c}
\hline Compound & $\begin{array}{c}\text { Lattice } \\
\text { constant, } \\
\AA\end{array}$ & $\begin{array}{c}\text { Grain } \\
\text { size, } \mu \mathrm{m}\end{array}$ & $\begin{array}{c}\text { Ceramics } \\
\text { density, } \\
\%\end{array}$ & $\sigma_{\mathrm{g}}, \mathrm{S} / \mathrm{m}$ & $\Delta E_{\mathrm{g}}, \mathrm{eV}$ & $\sigma_{\mathrm{tot}} \mathrm{S} / \mathrm{m}$ & $\Delta E_{\mathrm{tot}}, \mathrm{eV}$ & $\sigma_{\mathrm{gb}}, \mathrm{S} / \mathrm{m}$ & $\Delta E_{\mathrm{gb}}, \mathrm{eV}$ \\
\hline $10 \mathrm{GDC}_{\mathrm{com}}$ & $5.419(2)$ & $\sim 1.0$ & 91 & 0.21 & 0.75 & 0.17 & 0.78 & 0.9 & 0.93 \\
\hline $10 \mathrm{GDC}_{\mathrm{sg}}$ & $5.414(5)$ & $\sim 1.5$ & 83 & 0.16 & 0.72 & 0.05 & 0.92 & 0.07 & 1.00 \\
\hline
\end{tabular}



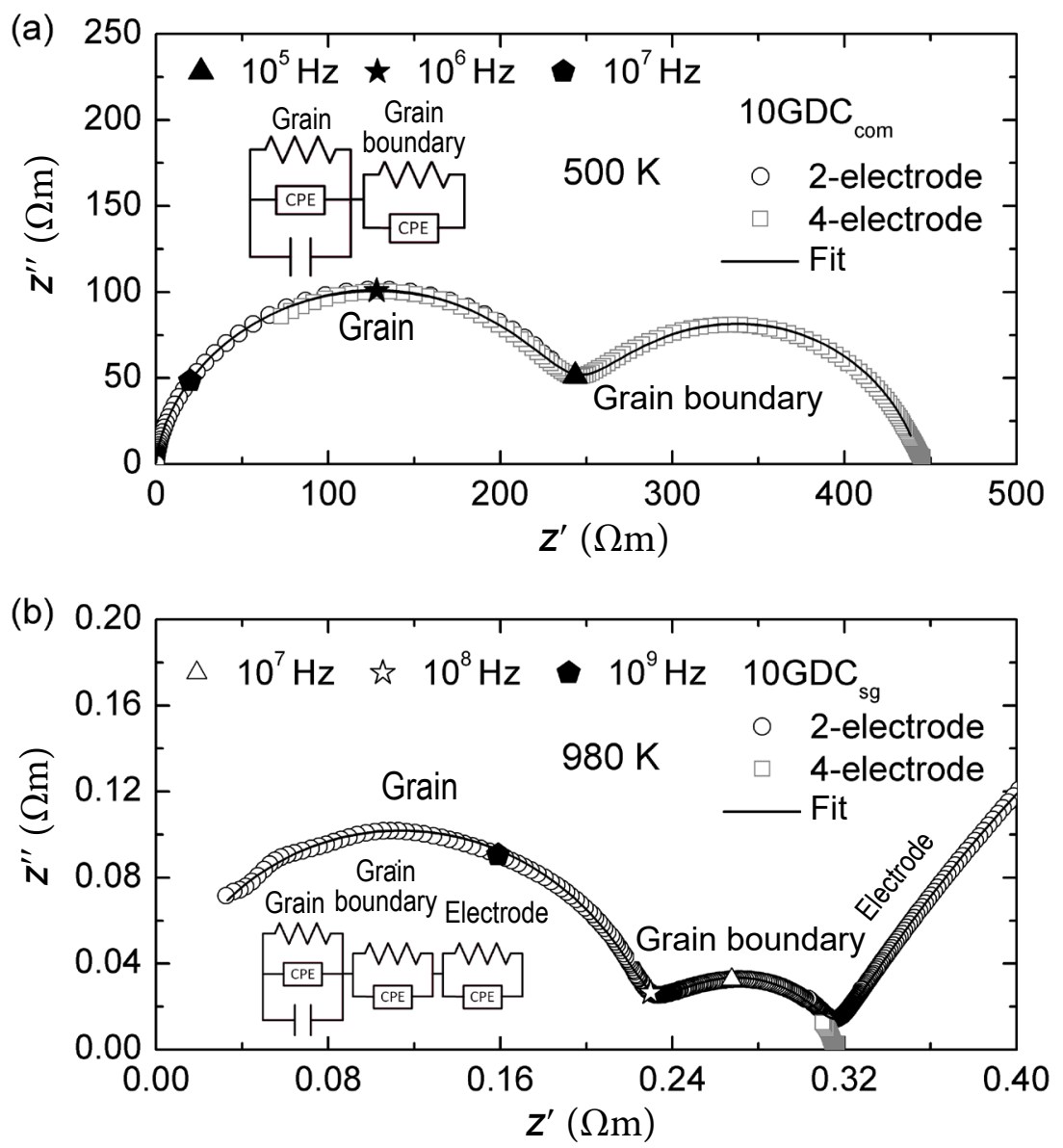

Fig. 4. Complex impedance plane plots of $10 \mathrm{GDC}_{\text {com }}$ (a) and $10 \mathrm{GDC}_{\mathrm{sg}}$ (b) measured at 500 and $980 \mathrm{~K}$, respectively. The indicative values of frequency are shown by the specific symbols.

and $1673 \mathrm{~K}[3-9$, respectively). The values of grain boundary conductivity at $673 \mathrm{~K}$ are presented in Table 1. In our previous work [23] it is shown that the grain boundary resistance of 10GDC ceramics approximately doubles when sintering temperature changes from 1573 to $1673 \mathrm{~K}$. However, in this case the grain boundary resistance of $10 \mathrm{GDC}_{\mathrm{sg}}$ is higher than that of $10 \mathrm{GDC}_{\text {com }}$ by $\sim 1.5$ orders in magnitude, indicating that other factors, such as the method of powder synthesis and sintering time, also made significant contributions. It also should be noted that in the case of 10GDC the grain boundary resistance becomes much lower than that of the grain at temperatures higher than $600 \mathrm{~K}$. Besides, the characteristic relaxation times in the grain and grain boundary get very close, the corresponding semicircles overlap and the separation of processes in the grain and grain boundary is complicated. Therefore the results of $10 \mathrm{GDC}_{\text {com }}$ in Fig. 5 are given in a limited temperature range.

Another important parameter of the grain boundary is the most probable relaxation frequency $f_{r_{-} g \mathrm{~b}}$, which corresponds to peak frequency in the spectra of the imaginary impedance part, or the top of a semicircle of the complex impedance plot. For example, Fig. 4(b) indicates that $f_{\mathrm{r}_{-} \mathrm{gb}}$ for $10 \mathrm{GDC}_{\text {sg }}$ at $980 \mathrm{~K}$ is about $10^{7} \mathrm{~Hz}$. Temperature dependences of $f_{r_{-} g b}$ (Fig. 6) indicate that the relaxation frequencies follow the Arrhenius plot with activation energies of 0.91 and $1.02 \mathrm{eV}$ for

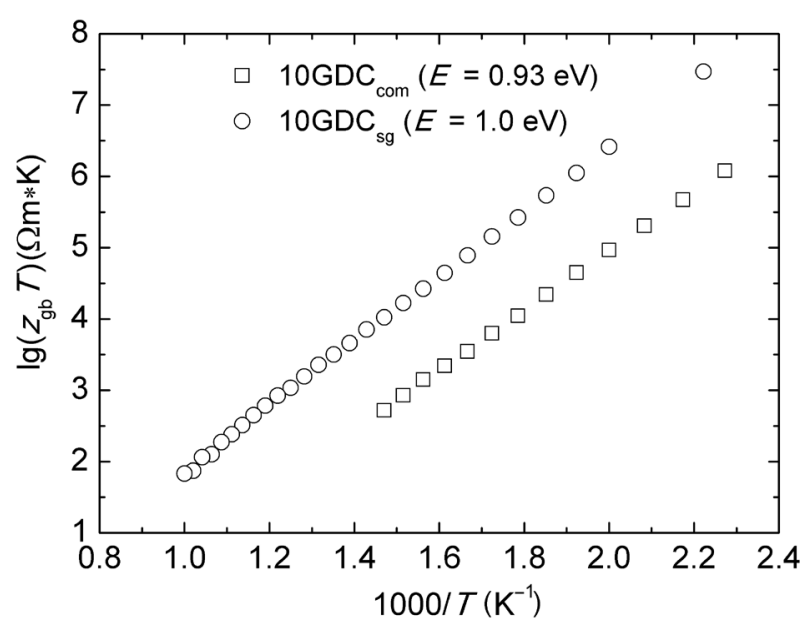

Fig. 5. Temperature dependences of grain boundary resistivity. 


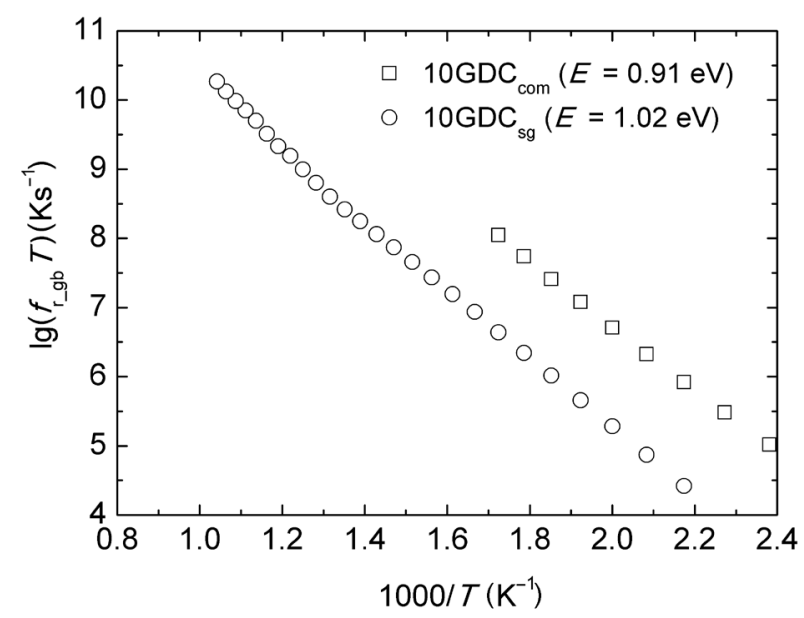

Fig. 6. Temperature dependences of the most probable relaxation frequency in grain boundary for both investigated ceramics.

$10 \mathrm{GDC}_{\mathrm{com}}$ and $10 \mathrm{GDC}_{\mathrm{sg}}$ ceramics, respectively. As it is evident, the obtained $f_{\mathrm{r} \_\mathrm{gb}}$ activation energies are almost identical to those of grain boundary resistivity. This indicates that the decrease of $f_{\mathrm{r}_{\mathrm{gb}}}$ with increasing temperature (Fig. 5) is essentially caused by the decrease of grain boundary resistivity, whereas the grain boundary capacity $C_{\mathrm{gb}} \approx\left(2 \pi f_{\mathrm{gb}} z_{\mathrm{gb}}\right)^{-1}$ is barely dependent on temperature.

Possibility to directly measure $f_{\text {r_gb }}$ also allows one to approximately estimate thicknesses of the grain boundary in $10 \mathrm{GDC}_{\mathrm{com}}$ and $10 \mathrm{GDC}_{\mathrm{sg}}$ ceramics. For this purpose one can take advantage of a brick-layer model [29], treating ceramics as arrays of cubic grains with the side $D$, separated by flat grain boundaries with the thickness of $d$. According to this model, a ratio between the thickness of the grain boundary medium and the dimension of the grain can be defined as [30]

$$
\frac{d}{D}=\frac{C_{\mathrm{gr}}}{C_{\mathrm{gb}}} \cdot \frac{\varepsilon_{\mathrm{gb}}}{\varepsilon_{\mathrm{gr}}},
$$

where $C_{\mathrm{gr}}$ and $\varepsilon_{\mathrm{gr}}$ are respectively the capacitance and permittivity of the grain, and $\varepsilon_{\mathrm{gb}}$ is the permittivity of the grain boundary. For rough estimates, it was assumed that $\varepsilon_{\mathrm{gb}}=\varepsilon_{\mathrm{gr}} D_{\text {com }}=1 \mu \mathrm{m}$ and $D_{\mathrm{sg}}=1.5 \mu \mathrm{m}$. The estimations of grain boundary thicknesses using capacitance data (measured at different temperatures) have shown that $d_{\text {com }}$ and $d_{\text {sg }}$ are in ranges of 6-8 and 6-10 $\mathrm{nm}$, respectively. Since the thicknesses of the grain boundary medium were found to be similar, it indicates that distinctions in the resistances of the grain boundary medium are essentially caused by different values of the specific resistivity of the grain boundary medium in $10 \mathrm{GDC}_{\mathrm{com}}$ and $10 \mathrm{GDC}_{\mathrm{sg}}$ ceramics.

The advantage of the 4-electrode method allowed us to obtain semicircles in complex impedance plain plots, representing the pure grain boundary response of the investigated ceramics. The obtained semicircles were found to be depressed (Fig. $4(a, b)$ ), suggesting that the associated relaxation times of the charge carrier deviate from that of an ideal Debye relaxation process: the more depressed semicircles, the broader the distributions of the relaxation times (DRT) of the charge carrier are. The semicircles representing the grain boundary response in $10 \mathrm{GDC}_{\mathrm{sg}}$ ceramics at two different temperatures are shown in Fig. ㄱ. In order to disclose differences in the arc depression, the experimental data were normalised to the same scale by operations indicated in the titles of axes. The latter data also show that the depression of semicircles representing the grain boundary response is more extensive at $800 \mathrm{~K}$ than that at $600 \mathrm{~K}$.

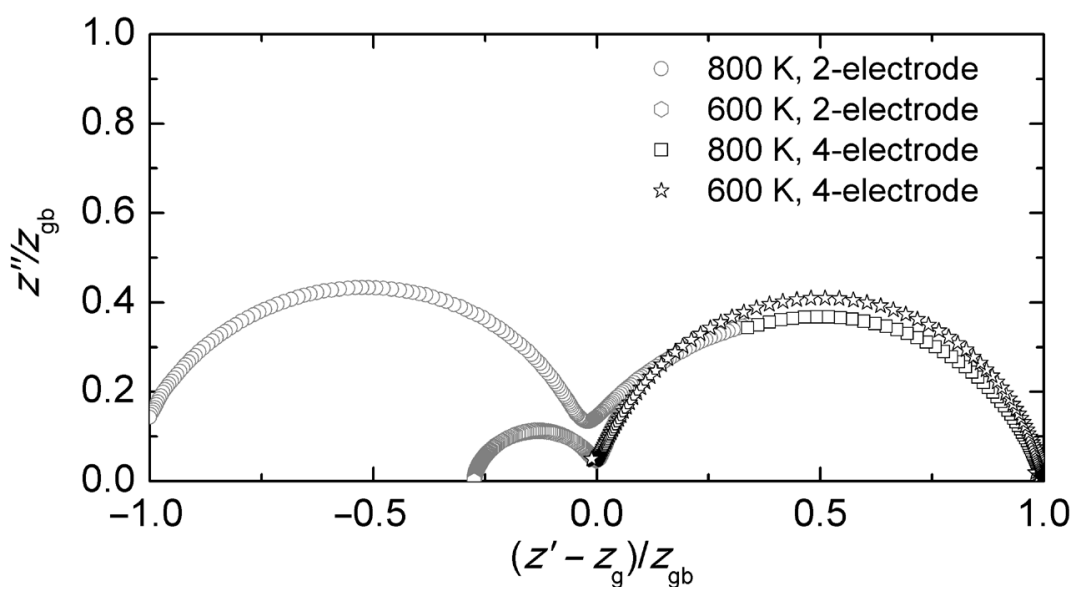

Fig. 7. Normalised impedance plane plots for $10 \mathrm{GDC}_{\mathrm{sg}}$ ceramics. 
A more detailed quantitative analysis of the experimental data for the grain boundary was carried out by estimating an invented parameter, which corresponds to the normalised imaginary impedance peak value $\alpha=z_{\mathrm{gb} \_ \text {peak }}^{\prime \prime} / z_{\mathrm{gb}}$, where $z_{\mathrm{gb} \text { _peak }}^{\prime \prime}$ is the imaginary impedance peak associated with the grain boundary. The closer the value of the ratio is to 0.5 , the less distributed relaxation times it indicates and vice versa. It was found that these ratios have different values for the grain boundaries of the ceramics sintered from different powders (Fig. 8). The parameter $\alpha$ is significantly lower for the ceramics with higher grain boundary resistivity $\left(10 \mathrm{GDC}_{\mathrm{sg}}\right)$, which means that at a fixed temperature the relaxation times of the charge carrier in the grain boundary are more widely distributed in the case of $10 \mathrm{GDC}_{\mathrm{sg}}$. However, the temperature dependences of the parameter $a$ were found to be uniform, since both ceramics have shown a regular decrease of the parameter $\alpha$ with temperature increase. Thus at lower temperatures the examined semicircles are less depressed compared to the ones at higher temperatures. That indicates the broadening of the DRT of the charge carrier with increasing temperature, contrary to the phenomenon observed in the grain of oxygen ion conductive ceramics and single crystals [31, 32].

The latter results may be explained as below. Let us assume that an equivalent circuit of a ceramic sample's grain boundary medium is composed of a sufficient number of Voigt elements in

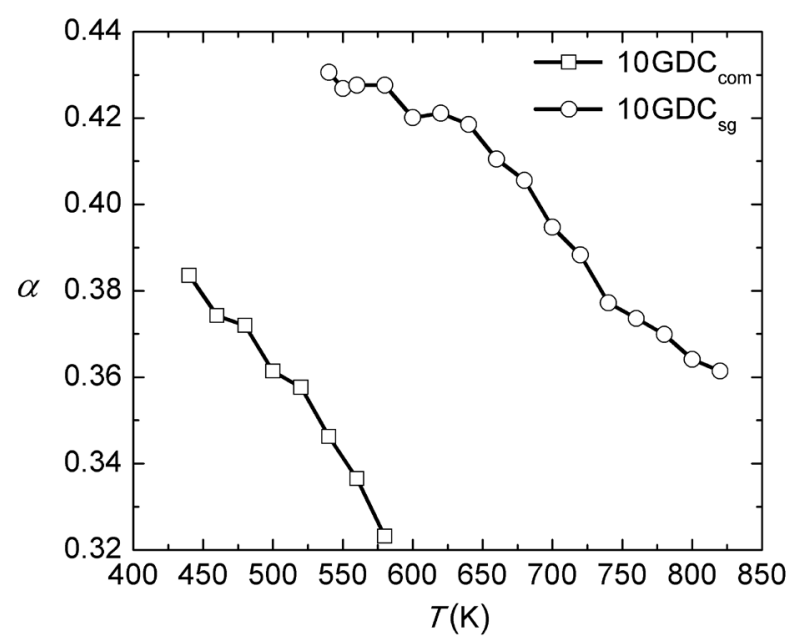

Fig. 8. Temperature dependences of the parameter $\alpha$, which represents the distortion of a grain boundary semicircle in the complex impedance plane plot. series with the distributed $R$ and non-distributed $C$. In such a case individual Voigt elements obey the Arrhenius law, whereas the resistance and relaxation time of each such element is defined by the activation energy and the pre-exponential factor. When the activation energy is solely distributed and the pre-exponential factor is not distributed among the elements, individual relaxation times will become less distributed with increasing temperature, and at infinite temperature all relaxation times would be the same and equal to the pre-exponential factor. Otherwise, when both the activation energy and the pre-exponential factor are distributed widely enough, relaxation times may become more distributed with increasing temperature. Since the grain boundary medium most likely has quite a various structure, stoichiometry and even chemical composition, it may be the cause of a large distribution of both the abovementioned parameters.

\section{Conclusions}

Electrical properties of two different 10GDC ceramics, one of which was prepared from the commercial powder and the second from the powder synthesised by the sol-gel method, were investigated at temperatures from 400 to $1000 \mathrm{~K}$. The XRD study has shown that both powders at room temperature have a cubic fluorite structure without any additional impurity phases, whereas the SEM images revealed larger crystallites and a notable porosity in $10 \mathrm{GDC}_{\mathrm{sg}}$ ceramics. The obtained grain conductivity values and activation energies of both investigated ceramics were almost the same and in close agreement with the previously reported data, whereas the values of total conductivity differ significantly due to different grain boundary resistivity of $10 \mathrm{GDC}_{\mathrm{sg}}$ and $10 \mathrm{GDC}_{\mathrm{com}}$. The grain boundary resistivity of $10 \mathrm{GDC}_{\text {com }}$ is lower by more than an order of magnitude and had lower activation energy when compared to $10 \mathrm{GDC}_{\mathrm{sg}}$, basically due to higher specific resistivity of the grain boundary.

Semicircles in complex impedance plain plots, related to the grain boundary response of the investigated ceramics, were found to be depressed. $10 \mathrm{GDC}_{\mathrm{sg}}$ exhibited a more distributed grain boundary relaxation process than that of $10 \mathrm{GDC}_{\mathrm{com}}$. Although the extent of DRT for these ceramics is 
different, the temperature dependence is almost identical in both cases, showing broadening of DRT with temperature increase. Supposing that individual relaxation times behave in accordance with the Arrhenius law, both the activation energy and the pre-exponential factor must be distributed. Such type of DRT is most likely related to a broad variety in the structure and chemical composition of the grain boundary medium.

\section{References}

[1] S. Zha, C. Xia, and G. Meng, Effect of Gd (Sm) doping on properties of ceria electrolyte for solid oxide fuel cells, J. Power Sources 115, 44-48 (2003).

[2] G. Accardo, D. Frattini, H.C. Ham, J.H. Han, and S.P. Yoon, Improved microstructure and sintering temperature of bismuth nano-doped GDC powders synthesized by direct sol-gel combustion, Ceram. Int. 44, 3800-3809 (2018).

[3] G. Dell'Agli, L. Spiridigliozzi, M. Pansini, G. Accardo, S.P. Yoon, and D. Frattini, Effect of the carbonate environment on morphology and sintering behaviour of variously co-doped (Ca, $\mathrm{Sr}, \mathrm{Er}$, Pr) Samarium-doped Ceria in co-precipitation/ hydrothermal synthesis, Ceram. Int. 44, 1793517944 (2018).

[4] S.I. Ahmad, T. Mohammed, A. Bahafi, and M.B. Suresh, Effect of Mg doping and sintering temperature on structural and morphological properties of samarium-doped ceria for IT-SOFC electrolyte, Appl. Nanosci. 7, 243-252 (2017).

[5] K.R. Lee, J.H. Lee, and H.I. Yoo, Grain size effect on the electrical properties of nanocrystalline ceria, J. Eur. Ceram. Soc. 34, 2363-2370 (2014).

[6] T.H. Santos, J.P.F. Grilo, F.J.A. Loureiro, D.P. Fagg, F.C. Fonseca, and D.A. Macedo, Structure, densification and electrical properties of $\mathrm{Gd}^{3+}$ and $\mathrm{Cu}^{2+}$ co-doped ceria solid electrolytes for SOFC applications: Effects of $\mathrm{Gd}_{2} \mathrm{O}_{3}$ content, Ceram. Int. 44, 2745-2751 (2018).

[7] S. Tariq, A. Marium, R. Raza, M.A. Ahmad, M.A. Khan, G. Abbas, M.W. Boota, S.K. Imran, S. Arshad, and M. Ikram, Comparative study of $\mathrm{Ce}_{0.80} \mathrm{Sm}_{0.20} \mathrm{Ba}_{0.80} \mathrm{Y}_{0.20} \mathrm{O}_{3-\mathrm{d}}$ (YB-SDC) electrolyte by various chemical synthesis routes, Results Phys. 8, 780-784 (2018).

[8] L. Spiridigliozzi, G. Dell'Agli, A. Marocco, G. Accardo, M. Pansini, S.P. Yoon, H.C. Ham, and D. Frattini, Engineered co-precipitation chemistry with ammonium carbonate for scalable synthesis and sintering of improved $\mathrm{Sm}_{0.2} \mathrm{Ce}_{0.8} \mathrm{O}_{1.90}$ and $\mathrm{Gd}_{0.16} \mathrm{Pr}_{0.04} \mathrm{Ce}_{0.8} \mathrm{O}_{1.90}$ electrolytes for IT-SOFCs, J. Ind. Eng. Chem. 59, 17-27 (2018).

[9] K. Reddy and K. Karan, Sinterability, mechanical, microstructural, and electrical properties of gadolinium-doped ceria electrolyte for low-temperature solid oxide fuel cells, J. Electroceramics 15, 45-56 (2005).

[10]M.A.F. Öksüzömer, G. Dönmez, V. Sariboğa, and T.G. Altinçekiç, Microstructure and ionic conductivity properties of gadolinia doped ceria $\left(\mathrm{Gd}_{x} \mathrm{Ce}_{1-x} \mathrm{O}_{2-x / 2}\right)$ electrolytes for intermediate temperature SOFCs prepared by the polyol method, Ceram. Int. 39, 7305-7315 (2013).

[11]G. Accardo, L. Spiridigliozzi, R. Cioff, C. Ferone, E. Di Bartolomeo, S.P. Yoon, and G. Dell'Agli, Gadolinium-doped ceria nanopowders synthesized by urea-based homogeneous co-precipitation (UBHP), Mat. Chem. Phys. 187, 149-155 (2017).

[12]K.C. Anjaneya, G.P. Nayaka, J. Manjanna, G. Govindaraj, and K.N. Ganesha, Preparation and characterization of $\mathrm{Ce}_{1-x} \mathrm{Gd}_{x} \mathrm{O}_{2-\delta}(x=0.1-0.3)$ as solid electrolyte for intermediate temperature SOFC, J. Alloys Compd. 578, 53-59 (2013).

[13]A.S. Babu, R. Bauri, and G.S. Reddy, Processing and conduction behavior of nanocrystalline Gddoped and rare earth co-doped ceria electrolytes, Electrochim. Acta 209, 541-550 (2016).

[14]P.C.C. Daza, R.A.M. Meneses, J.L.A. Ferreira, J.A. Araujo, A.C.M. Rodrigues, and C.R.M. da Silva, Influence of microstructural characteristics on ionic conductivity of ceria based ceramic solid electrolytes, Ceram. Int. 44(2), 2138-2145 (2018).

[15]R.O. Fuentes and R.T. Baker, Synthesis and properties of Gadolinium-doped ceria solid solutions for IT-SOFC electrolytes, Int. J. Hydrogen Energy 33, 3480-3484 (2008).

[16]D.W. Joh, M.K. Rath, J.W. Park, J.H. Park, K.H. Cho, S. Lee, K.J. Yoon, J.H. Lee, and K.T. Lee, 
Sintering behavior and electrochemical performances of nano-sized gadolinium-doped ceria via ammonium carbonate assisted co-precipitation for solid oxide fuel cells, J. Alloys Compd. 682, 188-195 (2016).

[17]S. Kulkarni, S. Duttagupta, and G. Phatak, Taguchi design of experiments for optimization of ionic conductivity in nanocrystalline Gadolinium doped Ceria, Ceram. Int. 41(7), 8973-8980 (2015).

[18]H.C. Lee, J.A. Lee, J.H. Lee, Y.W. Heo, and J.J. Kim, Ionic conductivity and relaxations of Indoped GDC (gadolinium doped ceria) ceramics, Ceram. Int. 43(15), 11792-11798 (2017).

[19]A. Arabaci and M.F. Öksüzömer, Preparation and characterization of $10 \mathrm{~mol} \% \mathrm{Gd}$ doped $\mathrm{CeO}_{2}$ (GDC) electrolyte for SOFC applications, Ceram. Int. 38, 6509-6515 (2012).

[20]A. Zarkov, A. Stanulis, T. Salkus, A. Kezionis, V. Jasulaitiene, R. Ramanauskas, S. Tautkus, and A. Kareiva, Synthesis of nanocrystalline gadolinium doped ceria via sol-gel combustion and sol-gel synthesis routes, Ceram. Int. 42(3), 39723988 (2016).

[21]W.J. Bowman, J. Zhu, R. Sharma, and P.A. Crozier, Electrical conductivity and grain boundary composition of Gd-doped and Gd/Pr co-doped ceria, Solid State Ion. 272, 9-17 (2015).

[22]A. Tschope, S. Kilassonia, and R. Birringer, The grain boundary effect in heavily doped cerium oxide, Solid State Ion. 173, 57-61 (2004).

[23]S. Kazlauskas, A. Kežionis, T. Šalkus, and A. Orliukas, Effect of sintering temperature on electrical properties of gadolinium-doped ceria ceramics, J. Mater. Sci. 50, 3246-3251 (2015).
[24]A. Kežionis, P. Butvilas, T. Šalkus, S. Kazlauskas, D. Petrulionis, T. Žukauskas, E. Kazakevičius, and A.F. Orliukas, Four-electrode impedance spectrometer for investigation of solid ion conductors, Rev. Sci. Instrum. 84, 013902 (2013).

[25]A. Kežionis, S. Kazlauskas, D. Petrulionis, and A.F. Orliukas, Broadband method for the determination of small sample's electrical and dielectric properties at high temperatures, IEEE Trans. Microw. Theory Tech. 62(10), 2456-2461 (2014).

[26]J.R. Dygas, Dielectric function of ionic conductors studied by impedance spectroscopy, Solid State Ion. 176(25-28), 2065-2078 (2005).

[27]A. Kežionis, S. Kazlauskas, D. Petrulionis, and A.F. Orliukas, Relationship between charge carrier relaxation and peculiarities of electric response in some solid oxygen ion conductors, Solid State Ion. 279, 25-31 (2015).

[28] Impedance Spectroscopy, Theory, Experiment and Applications, eds. E. Barsoukov and J.R. Macdonald (John Wiley and Sons, New Jersey, 2005).

[29]T. van Dijk and A.J. Burggraaf, Grain boundary effects on ionic conductivity in ceramic $\mathrm{Gd}_{x} \mathrm{Zr}_{1-x} \mathrm{O}_{2-(x / 2)}$ solid solutions, Phys. Status Solidi A 63, 229-240 (1981).

[30]J.R. Macdonald, Impedance Spectroscopy: Emphasizing Solid Materials and Systems (John Wiley \& Sons, New York, 1987).

[31]S. Kazlauskas, A. Kežionis, T. Šalkus, and A.F. Orliukas, Charge carrier relaxation in solid Vo conductors, Solid State Ion. 262, 593-596 (2014).

[32]S. Kazlauskas, A. Kežionis, T. Šalkus, and A.F. Orliukas, Electrical properties of YSZ and CaSZ single crystals, Solid State Ion. 231, 37-42 (2013). 


\title{
KRŪVININKỤ RELAKSACIJOS YPATYBĖS TARPKRISTALITINĖJE GADOLINIU LEGIRUOTŲ CERIO OKSIDO KERAMIKŲ TERPĖJE
}

\author{
S. Kazlauskas ${ }^{a}$, E. Kazakevičius ${ }^{a}$, A. Žalga ${ }^{\text {b }}$, S. Daugèla ${ }^{a}$, A. Kežionis ${ }^{a}$ \\ ${ }^{a}$ Vilniaus universiteto Taikomosios elektrodinamikos ir telekomunikaciju institutas, Vilnius, Lietuva \\ ${ }^{\mathrm{b}}$ Vilniaus universiteto Chemijos ir geologijos fakultetas, Vilnius, Lietuva
}

\begin{abstract}
Santrauka
Dviejų rūšių gadoliniu legiruoto cerio oksido keramikos buvo pagamintos iš skirtingų miltelių: vieni iš jų komerciniai, o kiti buvo sintezuojami zolių-gelių metodu, naudojant tartarinę rūgštį. Sukepintos keramikos turejjo skirtingą mikrostruktūrą, tačiau tyrimai rentgeno spindulių difrakcijos metodu rodè kubinio fluorito struktūrą be jokių priemaišinių fazių. Šių medžiagų elektrinès savybès buvo tiriamos iki $10 \mathrm{GHz}$ dažniuose naudojant 2-jų ir 4-ių elektrodų pilnutinès varžos spektroskopijos metodus.

Pirminiai elektrinių savybių tyrimo rezultatai parodé, kad keramikų kristalitų laidumai ir jų aktyvacijos energijos yra identiški. Tačiau dẻl skirtingų tarpkrista-
\end{abstract}

litinių terpių savybių bendrieji laidumai ir jų aktyvacijos energijos skyrèsi. Keturių elektrodų pilnutinès varžos spektroskopijos metodu buvo išmatuoti keramikų tarpkristalitinių terpių elektriniai atsakai. Pasitelkus šiuos duomenis buvo tiriamos krūvininkų relaksacijos trukmių pasiskirstymo keramikų tarpkristalitinėse terpèse temperatūrinès priklausomybès. Nustatyta, kad kylant temperatūrai šis pasiskirstymas didèja, priešingai, nei anksčiau stebètame analogiškame reiškinyje joninio laidumo keramikų kristalituose ir monokristaluose. Taip pat parodyta, kad manant, jog atskiros relaksacijų trukmès kinta pagal Arenijaus dèsnį, tiek aktyvacijos energija, tiek priešeksponentinis faktorius turi būti pasiskirstę. 